\title{
Inducible metabolism of fluoranthene by the opportunistic polychaete Capitella sp. I
}

\author{
Valery E. Forbes ${ }^{1, *}$, Thomas L. Forbes ${ }^{2}$, Marianne Holmer ${ }^{3}$ \\ ${ }^{1}$ Department of Life Sciences and Chemistry, Roskilde University, PO Box 260, DK-4000 Roskilde, Denmark \\ ${ }^{2}$ Department of Marine Ecology, National Environmental Research Institute, PO Box 358, Frederiksborgvej 399 , \\ DK-4000 Roskilde, Denmark \\ ${ }^{3}$ Institute of Biology, Odense University, Campusvej 55, DK-5230 Odense M, Denmark
}

\begin{abstract}
The polychaete Capitella sp. I has been described as an enrichment opportunist and is one of very few species able to thrive in highly organic sediments heavily contaminated with polycyclic aromatic hydrocarbons (PAH) and other organic pollutants. We examined 3 plausible explanations for the success of Capitella sp. l: (1) worms prevent uptake of PA.H across body surfaces, (2) worms take up PAH but metabolize them effectively to excretable forms, and (3) worms utilize PAH as a carbon source. We examined the uptake and depuration of sediment-associated fluoranthene by Capitella sp. 1 and measured the metabolic loss of ingested $3-\left[{ }^{14} \mathrm{C}\right]$ fluoranthene into particulate (POC), dissolved (DOC) and $\mathrm{CO}_{2}$ pools. Our results show that Capitella sp. I accumulates fluoranthene from sediment in a concentration-dependent manner, but that body burdens begin to decrease after $2 \mathrm{~d}$ and are undetectable by $7 \mathrm{~d}$ despite continued exposure to sediment fluoranthene concentrations of up to $360 \mu \mathrm{g}$ ( $\mathrm{g}$ dry wt sediment $)^{-1}$ Worms pre-exposed to PAH-contaminated sediment for 1 wk excreted substantially more ingested fluoranthene as DOC than control worms ( $37 \%$ vs $6 \%$ after 20 h), and retained significantly less fluoranthene in their tissues at the end of the experiment than control worms ( $33 \%$ vs $56 \%$ ). Our results are consistent with the hypothesis that Capitella sp. I metabolize fluoranthene, but contrary to our Hypotheses 1 and 3, worms did take up fluoranthene and did not appear to use it as a carbon source.
\end{abstract}

KEY WORDS: Sediment $\cdot$ Polycyclic aromatic hydrocarbon $\cdot$ PAH $\cdot$ Deposit feeder $\cdot$ Infauna

\section{INTRODUCTION}

It is widely recognized that sediment-dwelling infauna profoundly affect the physical and geochemical properties of sediments. The activities of deposit feeders have a major influence on the cycling of organic matter and on the fate of pollutants in benthic systems. Models developed to assess the influence of bioturbation on particle-sorbed pollutant diagenesis predict that areas of high bioturbation will behave as geochemical hot spots, tending to scavenge or accumulate pollutants (Aller 1982). Such models have also indicated that, as a result of their reworking activities, sediment-dwelling infauna may actually increase their

\footnotetext{
·E-mail:vforbes@virgil.ruc.dk
}

exposure to sediment-associated pollutants and so create a feedback loop between pollutant fate and effect (Forbes \& Forbes 1994).

The deposit-feeding polychaete Capitella capitata, originally believed to be a single species, is now known to consist of a complex of species that differ electrophoretically and in life history characteristics (Grassle \& Grassle 1974, 1976, Baoling et al. 1991, Gamenick \& Giere 1994). Capitella sp. I is the most opportunistic of the sibling species so far described that belong to this complex (Grassle \& Grassle 1974). It is a dominant inhabitant of sediments polluted heavily with organic matter from algae (e.g. Tsutsumi 1990), paper mills (e.g. Pearson \& Rosenberg 1976), fish farms (e.g. Tsutsumi et al. 1991), sewage sludge (e.g. Chang et al. 1992), and oil (e.g Sanders et al. 1980). The extent to which Capitella sp. I dominates such habitats 
is determined by an unusual tolerance to organic matter, metabolites, or associated pollutants versus its short generation time and high reproductive rates remains unclear (reviewed in Forbes et al. 1994). Tsutsumi and colleagues have suggested that Capitella spp. in fact require organically polluted sediment due to a very high need for protein in order to produce reproductively functional females (Tsutsumi 1987 , Tsutsumi et al. 1990).

Polycyclic aromatic hydrocarbons (PAH) constitute a broad class of environmentally persistent organic compounds that are now ubiquitous in both aquatic and terrestrial ecosystems (Shiaris 1989). Most are extremely insoluble, tend to be associated with particulate matter, especially sedimentary organics (National Oceanic and Atmospheric Administration 1989), are resistant to biodegradation and become increasingly refractory under reducing conditions (Hambrick et al. 1980, Delaune et al. 1981, Shiaris 1989). Biodegradation rates of PAH in sediments are enhanced in the presence of Capitella spp. (Gardner et al. 1979, Bauer et al. 1988). Less is known about the influence of PAH on the physiology and ecology of Capitella sp. I, but dominance of Capitella sp. I in oil-polluted sediments suggests that these polychaetes will frequently be exposed to high concentrations of $\mathrm{PAH}$ in nature.

We designed the following experiments to test 3 hypotheses explaining the relative success of Capitella sp. I in PAH contaminated sediments: (1) Capitella sp. I does not accumulate PAH from contaminated sediment, (2) Capitella sp. I accumulates PAH from contaminated sediment, but metabolizes it to an excretable form, and (3) Capitella sp. I uses sediment-associated PAH as a carbon source. We selected Capitella sp. I for study as it is the most opportunistic of the sibling species and we therefore expected it to show the most striking response to PAH exposure. We chose fluoranthene because it is one of the most abundant PAH identified in marine sediment samples (e.g. Shiaris \& Jambard-Sweet 1986, National Oceanic and Atmospheric Administration 1989), it tends to have a high bioaccumulation potential relative to smaller or larger PAH (Landrum 1989), it was shown to be highly toxic to benthic invertebrates $\left(\mathrm{LC}_{50}\right.$ values for Rhepoxynius abronius and Corophium spinicorne between 15 and $50 \mu \mathrm{g} \mathrm{H}^{-1}$; Swartz et al. 1990), and because a ${ }^{14} \mathrm{C}$ labeled form is commercially available.

\section{MATERIALS AND METHODS}

General. Capitella sp. I (identified by J. P. Grassle) were reared in laboratory culture in $10 \mathrm{l}$ aerated aquaria at $12^{\circ} \mathrm{C}$ and $30 \% \mathrm{~S}$ on a food source of frozen-thawed sediment $(<250 \mu \mathrm{m})$ augmented periodically with a mixture of 1 part dried spinach: 1 part Beauvais ${ }^{T 4}$ whole meal baby cereal: 1 part Tetramin ${ }^{M}$ commercial fish food by weight. Mature worms $>1$ to $2 \mathrm{~mm}^{3}$, without eggs, were used in the following experiments.

Worm size was estimated as body volume (Forbes \& Lopez 1987, Forbes et al. 1994). Worms were assumed to be cylindrical and each worm size estimate used in the analysis was the mean of 3 replicate volume determinations. Body volumes were measured by videotaping worms, with a camera mounted on a dissecting microscope. Worm length (L) and projected area (A) were estimated with JAVA (Jandel Inc., Erkrath, Germany) image analysis system and converted to volume $\left(V=\pi A^{2} / 4 L\right)$. Sediment for all experiments was collected from a shallow subtidal site in the Isefjord, island of Zealand, Denmark (Station 63; Rasmussen 1973), passed through either a $250 \mu \mathrm{m}$ or $125 \mu \mathrm{m}$ sieve, and frozen until use.

Fluoranthene uptake and depuration. We designed this experiment to examine uptake and depuration of sediment-associated fluoranthene by Capitella sp. I as a function of sediment fluoranthene concentration.

Fluoranthene-contaminated sediments were made by adding a known volume of fluoranthene stock solution [crystalline fluoranthene ( $98 \%$ GC grade, Aldrich) dissolved in acetone] to a known volume of wet sediment. Sediments were shaken for $62 \mathrm{~h}$ at $16^{\circ} \mathrm{C}$ in the dark, after which time they were allowed to settle, the overlying water was removed, and fresh seawater was added. Nominal concentrations were estimated by accounting for sediment water content (\%), density $\left(\mathrm{g} \mathrm{cm}^{-3}\right)$ and organic carbon content ( $\%$ dry wt). Sediment fluoranthene concentrations were chosen on the basis of published $\mathrm{LC}_{50}$ values (15 to $50 \mu \mathrm{g} \mathrm{l}^{-1}$ porewater for crustaceans; Swartz et al. 1990) which correspond to a sediment concentration of 30 to $90 \mu \mathrm{g}$ (g dry wt sed) ${ }^{-1}$ (for a sediment with $3 \%$ organic carbon; Swartz et al. 1990). Unpublished data from our laboratory showed little effect of a nominal sediment concentration of $90 \mu \mathrm{g}$ ( $\mathrm{g}$ dry wt sed $)^{-1}$ on survival and bioturbation by Capitella sp. I, so this was chosen as the minimum treatment concentration in the present experiment. Additional treatments were 180 and $360 \mu \mathrm{g}$ (g dry wt sed) ${ }^{-1}$ Purity of the fluoranthene was checked with ${ }^{13} \mathrm{C}-\mathrm{NMR}$ and GC/MS.

To each of eight 11 glass dishes we added $450 \mathrm{~g}$ sediment $(<250 \mu \mathrm{m}), 300 \mathrm{ml} 0.2 \mu \mathrm{m}$ filtered seawater $(32 \% \mathrm{~S})$, and 72 worms (average wet wt $2 \mathrm{mg}$ ), yielding a worm density of $5000 \mathrm{~m}^{-2}$ We used 2 dishes for the control and each of the 3 fluoranthene treatments. An additional 2 dishes containing the $90 \mu \mathrm{g} \mathrm{g}^{-1}$ treatment but no worms were used to check for microbial breakdown of fluoranthene in our sediment systems. Two dishes containing worms and uncontaminated sediment were used to measure background concen- 
trations of fluoranthene in sediment and worms. After $7 \mathrm{~d}$ of exposure, all worms were transferred to new dishes containing $450 \mathrm{~g}$ uncontaminated sediment so that depuration could be estimated during an additional 7 d. Five worms and 2 sediment samples were taken from each dish on Days $0,1,2,4,7,8,9,11$, and 14

Fluoranthene was extracted from sediment by first centrifuging $1 \mathrm{~cm}$ sediment core samples at $3000 \times g$ for $2 \mathrm{~min}$. After removal of the supernatant, the ca $0.5 \mathrm{~g}$ sediment remaining was extracted 3 times in hexane by briefly mixing with a Vortex mixer, followed by 10 min in a sonicating bath, and an additional 30 s on a Vortex mixer (L. Kure pers. comm.). Biphenyl (98\% GC grade, Aldrich) dissolved in methanol was added to every sample as an internal standard. Standard sediment containing $8.4 \pm 2.6 \mu \mathrm{g} \mathrm{g}^{-1}( \pm 95 \% \mathrm{CL})$ fluoranthene (National Research Council of Canada, Type HS-5) was used to test the accuracy of our extraction procedure. We could detect no significant difference between the reported fluoranthene concentration and that measured with our system.

Worms were rinsed of adhering sediment and allowed to clear their guts of sediment for $6 \mathrm{~h}$. Each group of 5 worms was added to a $10 \mathrm{ml}$ pyrex extraction tube and crushed with a glass spatula. To each tube were added $1 \mathrm{ml} 4 \mathrm{M} \mathrm{NaOH}$ and $1 \mathrm{ml}$ methanol containing the internal standard. The samples were incubated at $40^{\circ} \mathrm{C}$ for a minimum of $12 \mathrm{~h}$ (average $16 \mathrm{~h}$ ). After the samples were allowed to cool to room temperature, $1 \mathrm{ml} 4 \mathrm{M} \mathrm{HCl}$ was added and the samples were briefly mixed on a Vortex mixer. Samples were then extracted in hexane 3 times as for sediments.

Extracted samples were run on a Hewlett-Packard (HP) 5890II gas chromatograph (GC) coupled to an HP 5971A mass spectrometer and an HP MS data analyzer. We used an HP 1 nonpolar capillary column, selective ion monitoring, splitless injection, an injection volume of $1 \mu \mathrm{l}$, and a flow speed of $85 \mathrm{ml} \mathrm{s}^{-1}$ with helium as the carrier gas. The GC was temperature programmed, starting at $70^{\circ} \mathrm{C}$, increasing at a rate of $10^{\circ} \mathrm{C} \mathrm{min}^{-1}$, until a temperature of $300^{\circ} \mathrm{C}$ was reached. The detection limit on this machine was ca $100 \mathrm{ng} \mathrm{g}^{-1}$

${ }^{14} \mathrm{C}$-fluoranthene metabolism. Approximately 50 Capitella sp. I were removed from culture and randomly assigned to 1 of 2 food treatments: natural sediment $(<125 \mu \mathrm{m})$ or sediment $(<125 \mu \mathrm{m})$ to which a nominal concentration of $100 \mu \mathrm{g} \mathrm{g}^{-1}$ fluoranthene was added. The 2 treatments were set up in $100 \mathrm{ml}$ beakers, filled with ca $3 \mathrm{~cm}$ sediment and $17 \mathrm{~cm}$ aerated overlying seawater $\left(21^{\circ} \mathrm{C}, 30 \% \mathrm{~S}\right)$ and placed in the dark for $1 \mathrm{wk}$. On the day of the experiment, worms were removed from the feeding treatments, cleaned of adhering sediment and videotaped.
One day prior to the experiment, $2 \mathrm{ml}$ of sediment was labeled with $100 \mu \mathrm{Ci} 3-\left[{ }^{14} \mathrm{C}\right]$ fluoranthene (Sigma No. F6147) for $24 \mathrm{~h}$ at $21^{\circ} \mathrm{C}$ in the dark with periodic shaking. Immediately prior to the experiment, labeled sediment was centrifuged at $3000 \times g$ for $5 \mathrm{~min}$ and rinsed with $30 \% \mathrm{~S}, 0.2 \mu \mathrm{m}$ filtered seawater twice to remove unincorporated fluoranthene. Five $20 \mu \mathrm{l}$ replicate samples were taken to estimate sediment specific activity [dpm ${ }^{14} \mathrm{C}$ (mg dry wt sed $\left.)^{-1}\right]$.

Exactly $10 \mathrm{ml}$ of $30 \% \mathrm{~S}, 0.2 \mu \mathrm{m}$ filtered seawater and $35 \mu$ of ${ }^{14} \mathrm{C}$-labeled sediment were added to thirty $20 \mathrm{ml}$ plastic vials fitted with snap-on plastic lids. Fourteen worms from each of the 2 food treatments were placed in the prepared vials ( 1 worm per vial) and allowed to feed on the ${ }^{14} \mathrm{C}$-labeled sediment for $1 \mathrm{~h}$. Two vials were kept without worms to check for changes in sediment specific activity and loss of ${ }^{14} \mathrm{C}$ to the water phase during the $1 \mathrm{~h}$ feeding period. At the end of the hour, the contents of the 2 vials were filtered through $0.4 \mu \mathrm{m}$ Nuclepore ${ }^{\mathrm{TM}}$ filters, and the water and sediment phases counted separately for radioactivity.

Following the $1 \mathrm{~h}$ feeding period, worms were removed to clean seawater and cleaned of adhering radioactive sediment. They were transferred to new $20 \mathrm{ml}$ vials containing $10 \mathrm{ml}$ of $30 \% \mathrm{~S}, 0.2 \mu \mathrm{m}$ filtered seawater and $35 \mu \mathrm{l}$ of unlabeled sediment. Transfers were repeated after 1,5 and $20 \mathrm{~h}$. At each transfer, $3 \mathrm{ml}$ of overlying water was collected to estimate total dissolved ${ }^{14} \mathrm{C}$ (TDC). To separate dissolved organic carbon (DOC) from $\mathrm{CO}_{2}$, a second $3 \mathrm{ml}$ sample of water was added to a glass scintillation vial to which 3 drops of concentrated $\mathrm{H}_{3} \mathrm{PO}_{4}$ were added. The vial was fitted with a $\mathrm{CO}_{2}$ trap which consisted of a GF/C filter dampened with $20 \mu \mathrm{l}$ Soluene (Packard) tissue solubilizer and suspended above the water. The samples were shaken periodically for a minimum of $5 \mathrm{~h}$, after which time the $\mathrm{CO}_{2}$ traps were transferred to new scintillation vials and prepared for counting. Samples for $\mathrm{CO}_{2}$, DOC and TDC were prepared for counting by addition of $10 \mathrm{ml}$ Instagel (Packard) scintillation cocktail. Particulate material $\left(\mathrm{POC}={ }^{14} \mathrm{C}\right.$ contained in feces and mucus) was collected on a GF/C filter and prepared for counting by addition of $1 \mathrm{ml}$ Soluene and $10 \mathrm{ml}$ Instagel. Following the final transfer, worms were collected, cleaned of adhering sediment and prepared for counting by addition of $1 \mathrm{ml}$ Soluene and $10 \mathrm{ml}$ Instagel.

To check that bacteria associated with the sediment were not redistributing the ${ }^{14} \mathrm{C}$ pools during the period between transfers, we set up 6 vials in which we removed all worms at the $1 \mathrm{~h}$ transfer. The contents of 2 of the vials were prepared for counting immediately. 2 of the vials were kept without worms until the $5 \mathrm{~h}$ transfer and 2 vials were kept until the $20 \mathrm{~h}$ transfer, at which times their respective contents were prepared for counting. 
Samples were counted on a Wallac Model 1409 liquid scintillation counter, and were corrected for background and quench.

Statistical analyses. Changes in sediment fluoranthene concentration during the uptake and depuration experiment were analyzed by 1 -way analysis of variance (ANOVA), run separately for each exposure concentration. Pairwise differences in worm fluoranthene concentrations among Days 1, 2, and 4 were analyzed by Tukey's HSD test (tissue concentrations for Days 0 and 7 were below the detection limit for all treatment groups and were not included in the statistical analyses).

Differences in worm body volume between treatment groups in the ${ }^{14} \mathrm{C}$-fluoranthene metabolism experiment were analyzed by ANOVA. Since a significant difference in body size was detected between groups, additional analyses comparing the amount of ${ }^{14} \mathrm{C}$ ingested, the fraction of ingested ${ }^{14} \mathrm{C}$ lost as TDC, DOC, $\mathrm{CO}_{2}$ and $\mathrm{POC}$, and the fraction of ingested ${ }^{14} \mathrm{C}$ retained by worms were analyzed by analysis of $\mathrm{CO}$ variance, with treatment (control versus pre-exposed) as the grouping variable and body volume as the covariate. If body size and the body size $\times$ treatment interaction terms were not significant, a reduced ANOVA model was run to test for the effect of treatment alone. Statistical analyses were performed with SYSTAT 5.0 (Wilkinson 1990).

\section{RESULTS}

\section{Fluoranthene uptake and depuration}

Average measured concentrations for the 3 fluoranthene treatments and control sediment are shown in Table 1. We could not detect a change in sediment fluoranthene concentration during the $7 \mathrm{~d}$ exposure period in any of the treatments (ANOVA. $90 \mu \mathrm{g} \mathrm{g}^{-1}$ treatment, $\mathrm{p}=0.501 ; 180 \mu \mathrm{g} \mathrm{g}^{-1}$ treatment, $\mathrm{p}=0.559$; $360 \mu \mathrm{g} \mathrm{g}^{-1}$ treatment, $p=0.173$ ). Concentrations of fluoranthene in worm tissues at the start of the uptake experiment (Day 0) and in control treatments through-

Table 1. Measured sediment fluoranthene concentrations used in the uptake and depuration experiment. Values given are means $+\mathrm{SD}$ for 2 replicates

\begin{tabular}{cc}
$\begin{array}{c}\text { Nominal fluoranthene } \\
\text { concentration }\end{array}$ & $\begin{array}{c}\text { Measured fluoranthene } \\
\text { concentration }\end{array}$ \\
0 & $<$ Detection limit \\
90 & $116.2 \pm 59.16$ \\
180 & $165.0 \pm 76.29$ \\
360 & $369.8 \pm 152.30$ \\
\hline
\end{tabular}

out the course of the experiment were below detection. The pattern of tissue fluoranthene concentration showed an increasing trend during the first $2 \mathrm{~d}$ of exposure and then a decrease between Days 2 and 4 (Fig. 1). Body burdens of fluoranthene after $1 \mathrm{~d}$ of exposure were linearly related to sediment concentration (Fig. 2). However, for all treatments, tissue concentrations were below detection by Day 7 . Given that tissue concentrations had decreased below the detection limit despite continued exposure, data for the $7 \mathrm{~d}$ depuration period (Days 8 to 14) were excluded from the analysis. Comparison among Days 1,2 , and 4 indicated that, for the 90 and $180 \mu \mathrm{g} \mathrm{g}^{-1}$ treatments, tissue concentrations were lower on Day 4 than on Days 1 and 2 (Tukey HSD test, $p \leq 0.02$ ). The difference in tissue concentration between days was not significant in the $360 \mu \mathrm{g} \mathrm{g}^{-1}$ treatment, primarily as a result of the high variability between replicates for Day 2 isee Fig. 1; Tukey HSD, Day 2 vs Day 4, $p=0.107$ ), but the trend in tissue concentrations was the same as in the other treatments.

\section{${ }^{14} \mathrm{C}$-fluoranthene metabolism}

At the end of the $1 \mathrm{wk}$ fluoranthene pre-exposure period, fluoranthene-exposed worms were significantly smaller on average than worms from control sediment [control: $8.95 \mathrm{~mm}^{3}( \pm 1.678=\mathrm{SD})$; pre-exposed. $\left.5.25 \mathrm{~mm}^{3}( \pm 1.415=\mathrm{SD})\right]$. Thus, all further comparisons between treatment and control groups included body volume as a covariate. If body size had no detectable effect on the test variable of interest, a simpler model was used in which body size was deleted from the analysis.

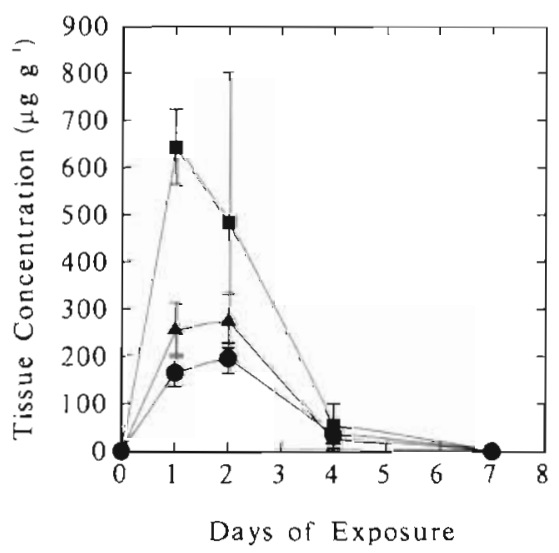

Fig. 1. Capitella sp. I. Fluoranthene uptake and depuration. Worms were exposed to fluoranthene-contaminated sediments for 7 d at concentrations of $(\bullet) 90 \mathrm{\mu g} \mathrm{g}^{-1},(\mathbf{\Lambda}) 180 \mathrm{~kg} \mathrm{~g}^{-1}$ or (1) $360 \mathrm{\mu g} \mathrm{g}^{-1}$. Points represent the means of 2 replicates of 5 worms each. Error bars are standard deviations 


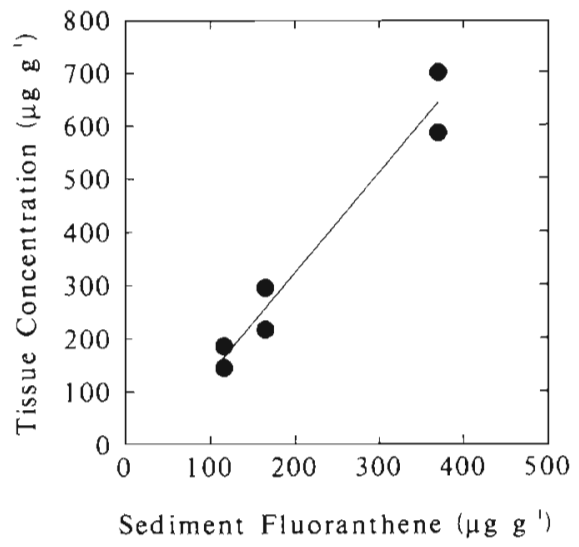

Fig. 2. Capitella sp. I. Tissue fluoranthene concentration as a function of sediment fluoranthene concentration after $1 \mathrm{~d}$ of exposure. Tissue concentration: $-53.61( \pm 45.997=\mathrm{SE})+$ $1.88( \pm 0.189=\mathrm{SE})$ sediment concentration; $\mathrm{n}=6, \mathrm{r}^{2}=0.96$, $\mathrm{p}=0.001$

The specific activity of ${ }^{14} \mathrm{C}$-fluoranthene in sediment was estimated to be $228 \mathrm{dpm}$ ( $\mu \mathrm{g}$ sed dry $w \mathrm{t}^{-1}$, which corresponds to a concentration of $376 \mu \mathrm{g}$ fluoranthene (g dry wt sed) $)^{-1}$. There was no change in the sediment specific activity during the course of the $1 \mathrm{~h}$ feeding period, but an average of $5.5 \%( \pm 2.83=\mathrm{SD})$ of the ${ }^{14} \mathrm{C}$ was associated with the water and particles $<0.4 \mu \mathrm{m}$ at the end of the feeding period.

The total amount of fluoranthene ingested during the $1 \mathrm{~h}$ feeding period was a function of worm size (ANCOVA, $p=0.024$ ) but did not differ between preexposed and control groups $(p=0.874)$, (Fig. 3$)$. The

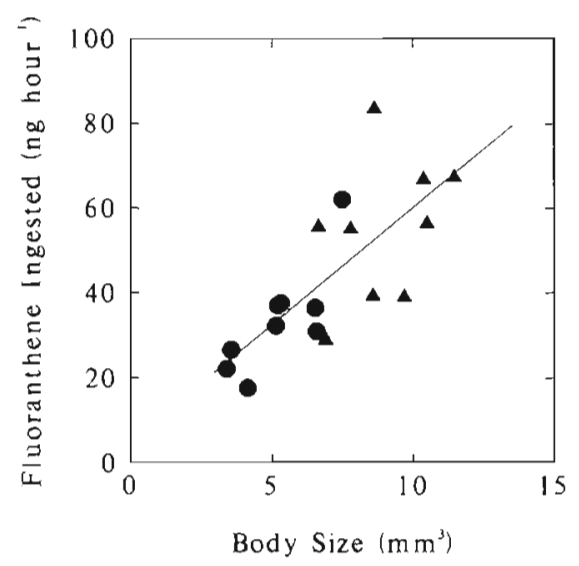

Fig. 3. Capitella sp. I. $\left.3-1^{14} \mathrm{C}\right]$ fluoranthene metabolism. Amount of fluoranthene ingested during a $1 \mathrm{~h}$ feeding period was influenced by worm size but not pre-exposure treatment. (४) Control worms, (1) worms pre-exposed to fluoranthene for 1 wk. Regression for all points pooled: $\log$ (ng fluoranthene Ingested $)=0.86( \pm 0.148=\mathrm{SE})+0.91( \pm 0.176=\mathrm{SE}) \log ($ worm volume); $\mathrm{n}=18, \mathrm{r}^{2}=0.626, \mathrm{p}<0.001$

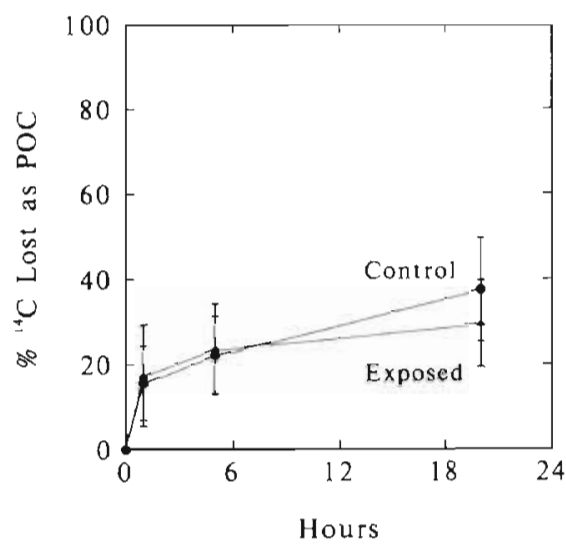

Fig. 4. Capitella sp. 1. $3-\left[{ }^{14} \mathrm{C}\right]$ fluoranthene metabolism. Fraction of ingested fluoranthene lost as POC during $20 \mathrm{~h}$ following the labeled meal. Data are presented as the mean and standard deviation of 9 worms each in the control and exposed groups

fraction of ingested ${ }^{14} \mathrm{C}$ lost in feces and mucus (= POC) during $20 \mathrm{~h}$ following the labeled meal was independent of body volume and did not differ between control and pre-exposed groups (Fig. 4). By $20 \mathrm{~h}$, the fraction of ingested ${ }^{14} \mathrm{C}$ lost as POC was $37.5 \%( \pm 12.14)$ in the control group and $29.5 \%( \pm 10.16)$ in the pre-exposed group. The fraction of ingested ${ }^{14} \mathrm{C}$ lost as $\mathrm{CO}_{2}$ was independent of worm size and did not differ between control and pre-exposed groups (Fig. 5). An average of $0.58 \%$ of the ingested ${ }^{14} \mathrm{C}$ was lost as $\mathrm{CO}_{2}$ by $20 \mathrm{~h}$ in both control and pre-exposed groups (control $\mathrm{SD}=$ 0.286 ; pre-exposed $\mathrm{SD}=0.252$ ) .

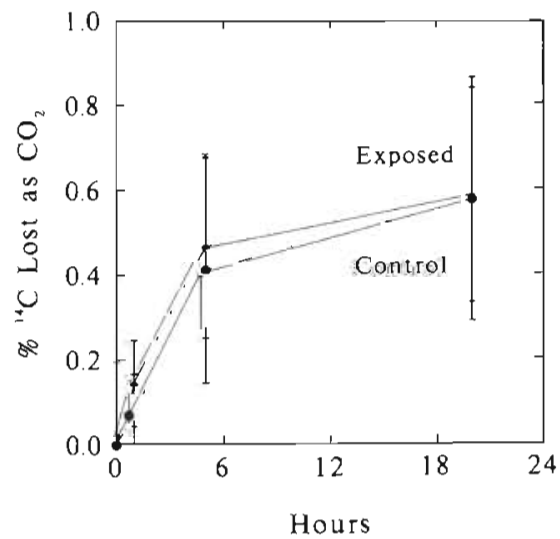

Fig. 5. Capitella sp. 1. 3-[ $\left[{ }^{14} \mathrm{C}\right]$ fluoranthene metabolism. Fraction of ingested fluoranthene lost as $\mathrm{CO}_{2}$ during $20 \mathrm{~h}$ following the labeled meal. Data are presented as the mean and standard deviation of 9 worms each in the control and exposed groups 


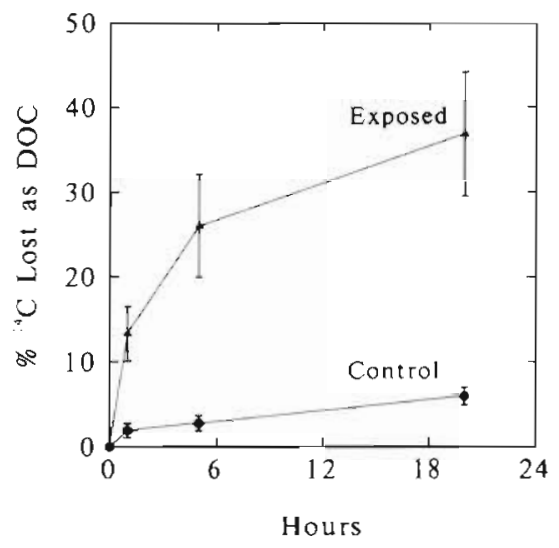

Fig. 6. Capitella sp. I. $3-\left[{ }^{14} \mathrm{C}\right]$ fluoranthene metabolism. Fraction of ingested fluoranthene lost as DOC during $20 \mathrm{~h}$ following the labeled meal. Data are presented as the mean and standard deviation of 9 worms each in the control and exposed groups

The fraction of ingested ${ }^{14} \mathrm{C}$ lost as DOC during $20 \mathrm{~h}$ following the labeled meal was significantly higher in pre-exposed relative to control worms (Fig. 6). In addition, the fraction lost as DOC was independent of size in control worms $(p=0.135)$ but was inversely related to size in pre-exposed worms $(\mathrm{p}=0.009 ;$ Fig. 7$)$. By $20 \mathrm{~h}$, the mean fractions lost as DOC were $5.96 \%$ $( \pm 1.03=S D)$ in the control group and $36.82 \%( \pm 7.35)$ in

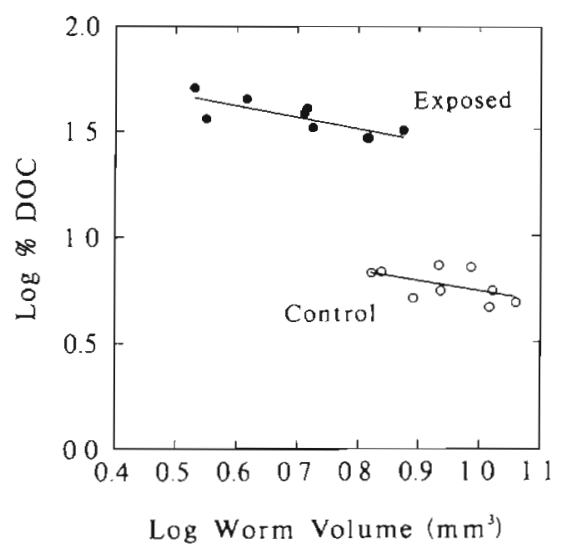

Fig. 7. Capitella sp. I. $3-\left[{ }^{14} \mathrm{C}\right]$ fluoranthene metabolism. Allometric relationships between fractional DOC loss (total for the $20 \mathrm{~h}$ period) and worm body volume.

For control worms:

$\log (\% \mathrm{DOC})=$

$1.23( \pm 0.276 \mathrm{SE})-0.49( \pm 0.291 \mathrm{SE}) \log ($ worm volume) $\mathrm{n}=9, \mathrm{r}^{2}=0.289, \mathrm{p}=0.135$

For pre-exposed worms

$\log (\% \mathrm{DOC})=$

$1.95( \pm 0.112 \mathrm{SE})-0.56( \pm 0.157 \mathrm{SE}) \log$ (worm volume) $\mathrm{n}=9, \mathrm{r}^{2}=0.644, \mathrm{p}=0.009$

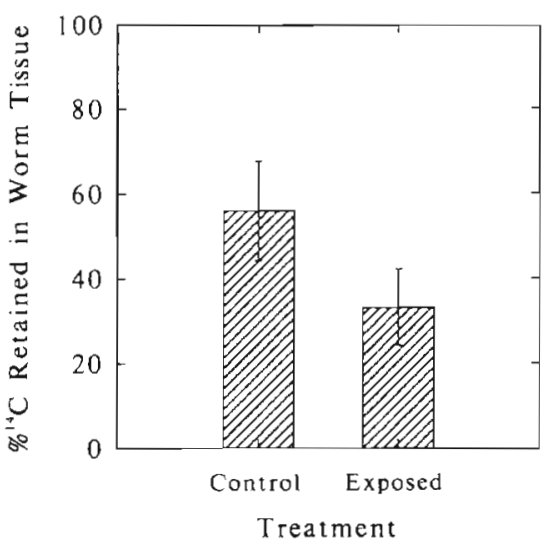

Fig. 8. Capitella sp. 1. 3-[ $\left[{ }^{14} \mathrm{C}\right]$ fluoranthene metabolism. Fraction of ingested fluoranthene retained in worm tissues after $20 \mathrm{~h}$ following the labeled meal. Data are presented as the mean and standard deviation of 9 worms each in the control and exposed groups

the pre-exposed group. Differences between groups were already detectable after $1 \mathrm{~h}$ following the labeled meal, at which time the control group had lost $1.9 \%$ $( \pm 0.86)$ and the pre-exposed group $13.3 \%( \pm 3.21)$ of the ingested ${ }^{14} \mathrm{C}$ as DOC.

The fraction of ingested ${ }^{14} \mathrm{C}$ still retained by worm tissues after $20 \mathrm{~h}$ was independent of body volume but was significantly higher in control relative to preexposed worms (Fig $8 ; p<0.001$ ). Control worms retained $56.0 \%( \pm 11.7=\mathrm{SD})$ and pre-exposed worms $33.2 \%( \pm 9.0=\mathrm{SD})$ of the ingested ${ }^{14} \mathrm{C}$ in their tissues.

In order to check for loss of $\mathrm{CO}_{2}$ during separation of TDC into $\mathrm{DOC}$ and $\mathrm{CO}_{2}$ fractions, we regressed measured TDC against predicted TDC ( = sum of DOC + $\mathrm{CO}_{2}$ ). The agreement was very good and the recovery of TDC in the separated samples averaged $88 \%$ The above values for $\mathrm{DOC}$ and $\mathrm{CO}_{2}$ were not corrected for percentage recovery, as doing so would have had a negligible effect on the results and would not have altered our major conclusions.

We were concerned that bacteria associated with the sediment might redistribute the ${ }^{14} \mathrm{C}$ pools between transfer periods. We were particularly concerned that bacteria would convert $\mathrm{DO}^{14} \mathrm{C}$ or $\mathrm{PO}^{14} \mathrm{C}$ to ${ }^{16} \mathrm{CO}_{2}$. To test for this effect, we compared the $\mathrm{DOC} / \mathrm{CO}_{2}$ and $\mathrm{POC} / \mathrm{CO}_{2}$ ratios for vials in which the worms were removed at the $1 \mathrm{~h}$ transfer, but were allowed to incubate for 0,5 or $20 \mathrm{~h}$ following worm removal (see 'Materials and methods'). There was no significant change in either ratio as a function of incubation time, indicating that potential bacterial redistribution of carbon pools did not bias our results (Kruskal-Wallis test: $\mathrm{DOC} / \mathrm{CO}_{2}, K_{\mathrm{s}}=0.857, \mathrm{p}=0.651 ; \mathrm{POC} / \mathrm{CO}_{2}, K_{\mathrm{s}}=2.000$, $\mathrm{p}=0.368)$. 


\section{DISCUSSION}

The opportunistic polychaete Capitella sp. I accumulated fluoranthene from contaminated sediment in a concentration-dependent manner. This result does not support the hypothesis that worms do not take up PAH from contaminated sediment (Hypothesis 1). Highest body burdens were achieved during the first $2 \mathrm{~d}$ of exposure, after which time tissue concentrations decreased and were below detection by Day 7 at all sediment concentrations, despite continued exposure to high sediment fluoranthene concentrations. Net bioconcentration factors were 1.7 for the 3 treatments on Day 2. There was little or no mortality of Capitella sp. I in any of our sediment treatments and worms appeared to be actively feeding, despite the fact that the concentrations of fluoranthene used in the uptake experiment (90 to $360 \mu \mathrm{g} \mathrm{g}^{-1}$ ) were high relative to reported values for heavily contaminated marine sediments (Shiaris \& Jambard-Sweet 1986, National Oceanic and Atmospheric Administration 1989).

Ingestion rates of ${ }^{14} \mathrm{C}$-fluoranthene were linearly related to body volume but did not differ as a function of fluoranthene treatment. If we assume that control and pre-exposed worms had similar particle selectivity, then the amount of sediment ingested (which is proportional to the amount of fluoranthene ingested multiplied by an index of selectivity) did not differ as a function of fluoranthene treatment. This indicates that the pre-exposure to high sediment fluoranthene concentrations, although reducing growth rate, did not irreversibly reduce feeding rate relative to the control group.

On the basis of stable isatope ratios, Spies et al (1989) concluded that Capitella species, living in the vicinity of oil seeps, utilize petroleum as a carbon source. The results of our ${ }^{14} \mathrm{C}$-fluoranthene metabolism experiment do not support the hypothesis that Capitella sp. I can use fluoranthene as a carbon source to any great degree. Less than $1 \%$ of the ingested ${ }^{14} \mathrm{C}$ was respired as $\mathrm{CO}_{2}$. Typical ${ }^{14} \mathrm{CO}_{2}$ release values for other invertebrates fed ${ }^{14} \mathrm{C}$-labeled food sources are in the range of $27 \%$ (Hydrobia ulvae; Forbes \& Depledge 1992) to 30-53\% (Hydrobia ventrosa; Kofoed 1975) of the ingested ${ }^{14} \mathrm{C}$ during the first day.

Pre-exposure for $1 \mathrm{wk}$ to fluoranthene-contaminated sediment increased the fraction of ingested ${ }^{14} \mathrm{C}$ fluoranthene lost as DOC and decreased the fraction retained in worm tissues at the end of the experiment. These results provide evidence for an inducible metabolic pathway resulting in increased excretion of fluoranthene-derived metabolites in pre-exposed worms The concentration of ${ }^{14} \mathrm{C}$-labeled fluoranthene used in the metabolism study was high relative to reported values for heavily polluted sediment (Shiaris \& Jambard-Sweet 1986, National Oceanic and Atmospheric
Administration 1989). Despite such high levels used, we did detect significant excretion of fluoranthene-derived ${ }^{14} \mathrm{C}$, even in control worms, indicating either some degree of background enzyme activity or rapid induction following a very brief duration of exposure (i.e. by 1 h). Previous work by Lee \& Singer (1980) demonstrated increased mixed function oxygenase (MFO) activity in Capitella (sibling species unidentified) following exposure to benz[a]anthracene for 3,6 and $10 \mathrm{wk}$ and increased activity following exposure to Kuwaiti crude oil after 10 (but not 3 or 6) wk. Those authors could not detect any MFO activity in unexposed worms. Although their results clearly indicated increased MFO activity in response to PAH or oil exposure, the extent to which the increase reflected induction versus selection for genetic strains with high enzyme activity could not be determined. Our results indicate that the metabolic pathways responsible for transforming PAH into soluble excretory products are inducible over a period of a few days of exposure. Determining whether or not it is the same MFO enzymes identified by Lee \& Singer (1980) or different enzymes that are induced in Capitella sp. I after a few days' exposure to $\mathrm{PAH}$ will require further investigation.

The dissolved fluoranthene metabolites released by Capitella sp. I were apparently not readily available for microbial attack since DOC pools were not detectably converted to $\mathrm{CO}_{2}$ during an incubation period of up to $19 \mathrm{~h}$. This is in contrast to results of experiments in which the fate of known food sources, labeled with ${ }^{14} \mathrm{C}$ and fed to invertebrates, has been traced in closed systems. In such cases, the DOC excreted may be measurably mineralized to $\mathrm{CO}_{2}$ by microbial activities (e.g. Parsons et al. 1984, p. 217; Forbes \& Depledge 1992).

The MFO system is a primary pathway by which foreign lipophilic compounds are converted into more water soluble metabolites for excretion, and study of the role of this system has generally focused on assays of MFO activity and the amount of cytochrome P-450 (reviewed in Lee 1981). The limited sensitivity of currently available assays for $\mathrm{MFO}$ activity requires that entire Capitella be homogenized and pooled for analysis. Because the use of whole animals may dilute the signal if only certain tissues show inducible activity and because MFO inhibitors may be released during homogenization, the usefulness of this approach is limited for small invertebrates such as Capitella. Lee \& Singer (1980) reported relatively low levels of MFO activity in Capitella spp. exposed to crude oil (compared to measurements of separate organs of larger invertebrates; Lee 1981), despite the fact that Capitella species are generally among the first to recolonize oil contaminated sites in the field (e.g. Sanders et al. 1980). An advantage of our approach to assessing 
metabolism of PAH over that of direct measures of MFO activity is that we measure the metabolic response of individual, intact, actively feeding worms in sediments. Our results demonstrate that Capitella sp. I, exposed to highly contaminated sediment, can metabolize PAH such that body burdens are unmeasurable after a few days.

Acknowledgements. We are grateful to Ole Andersen for critical comments on the manuscript, to Torben Lund for advice and assistance with fluoranthene measurements and to Anne Grete Sørensen for keeping the laboratory under control. In addition, we extend our sincere thanks to Peter Fatum, Anders Michael Bernth Giessing, Rikke Hansen, Anja Skjoldborg Hansen, Anders Feilberg Jorgensen, and Mikkel $P$. Østergaard for the use of their unpublished uptake and depuration data. We thank $\mathrm{L}$. Kure for advice on fluoranthene extraction procedures. This work was supported by grants from the Danish National Science Council, No. 11-0954-1 to O. Andersen and No. 11-1047. 1 to T.L.F.

\section{LITERATURE CITED}

Aller RC (1982) The effects of macrobenthos on chemical properties of marine sediment and overlying water. In McCall PL, Tevesz MJS (eds) Animal-sediment relations: the biogenic alteration of sediments, 2 nd vol. Topics in Geobiology. Plenum Press, New York, p 53-102

Baoling W, Pei-Yuan Q, Sonling Z (1991) Morphology, reproduction, ecology and allozyme electrophoresis of three Capitella sibling species in Qingdao (Polychaeta: Capite)lidae). Ophelia Suppl 5:391-400

Bauer J, Kerr R, Bautista MF, Decker CJ, Capone DG (1988) Stimulation of microbial activities and polycyclic aromatic hydrocarbon degradation in marine sediments inhabited by Capitella capitata. Mar environ Res 25:63-84

Chang S, Steimle FW, Reid RN, Fromm SA, Zdanowicz VS, Pikanowski RA (1992) Association of benthic macrofauna with habitat types and quality in the New York Bight. Mar Ecol Prog Ser 89:237-251

DeLaune RD, Patrick WH, Casselman ME (1981) Effect of sediment $\mathrm{pH}$ and redox conditions on degradation of benzo(a)pyrene. Mar Pollut Bull 12:251-253

Forbes TL, Forbes VE, Depledge MH (1994) Individual physiological responses to environmental hypoxia and organic enrichment: implications for early soft-bottom community succession. J mar Res 52:1081-1100

Forbes TL, Lopez GR (1987) The allometry of deposit feeding in Capitella species I (Polychaeta: Capitellidae): the role of temperature and pellet weight in the control of egestion. Biol Bull 172:187-201

Forbes VE, Depledge MH (1992) Cadmium effects on the carbon and energy balance of mudsnails Mar Biol 113:263-269

Forbes VE, Forbes TL (1994) Ecotoxicology in theory and practice. Chapman \& Hall, London

Gamenick I, Giere O (1994) Population dynamics and ecophysiology of Capitella capitata from North Sea intertidal flats: evidence for two sibling species. Polychaete Res 16:44-47

Gardner WS, Lee RF, Tenore KR, Smith LW (1979) Degradation of selected polycyclic aromatic hydrocarbons in coastal sediments: importance of microbes and polychaete worms. Wat Air Soil Pollut 11:339-347

Grassle JF, Grassle JP (1974) Opportunistic life histories and genetic systems in marine benthic polychaetes. J mar Res $32: 253-284$
Grassle JP, Grassle JF (1976) Sibling species in the marine pollution indicator Capitella (Polychaeta). Science 192: $567-569$

Hambrick GA III, DeLaune RD, Patrick WH Jr (1980) Effect of estuarine sediment $\mathrm{pH}$ and oxidation-reduction potential on microbial hydrocarbon degradation. Appl environ Microbiol 40:365-369

Kofoed LH (1975) The feeding biology of Hydrobia ventrosa (Montagu). II. Allocation of the components of the carbonbudget and the significance of the secretion of dissolved organic material. J exp mar Biol Ecol 19:243-256

Landrum PF (1989) Bioavailability and toxicokinetics of polycyclic aromatic hydrocarbons sorbed to sediments for the amphipod Pontoporeia hoyi. Environ ScI \& Technol 23:588-595

Lee RF (1981) Mixed function oxygenases (MFO) in marine invertebrates. Mar Biol Lett 2:87-105

Lee RF, Singer SC (1980) Detoxifying enzymes in marine polychaetes: increases in activity after exposure to aromatic hydrocarbons. Rapp P-v Reun Cons int Explor Mer 179:29-32

National Oceanic and Atmospheric Administration (1989) An cvaluation of candidate measures of biological effects for the National Status and Trends Program. NOAA Technical Memorandum NOS OMA 45, National Oceanic and Atmospheric Administration, Seattle, WA

Parsons TR, Takahashi Ml, Hargrave B (1984) Biological oceanographic processes, 3rd edn. Pergamon Press, Oxford

Pearson TH, Rosenberg R (1976) A comparative study of the effects on the marine environment of wastes from cellulose industries in Scotland and Sweden. Ambio 5:77-79

Rasmussen E (1973) Systematics and ecology of the Isefjord marine fauna (Denmark). Ophelia 11:1-507

Sanders HL, Grassle JF, Hampson GR, Morse LS, GarnerPrice S, Jones CC (1980) Anatomy of an oil spill: long term effects of the grounding of the barge 'Florida' off West Falmouth, Massachusetts. J mar Res 38:265-380

Shiaris MP (1989) Seasonal biotransformation of napthalene, phenanthrene, and benzo(a)pyrene in surficial estuarine sediments. Appl environ Microbiol 55:1391-1399

Shiaris MP, Jambard-Sweet D (1986) Polycyclic aromatic hydrocarbons in surficial sediments of Boston Harbour, Massachusetts, USA. Mar Pollut Bull 17:469-472

Spies RB, Bauer JE, Hardin D (1989) Stable isotope study of sedimentary carbon utilization by Capitella spp.: effects of two carbon sources and geochemical conditions during their diagenesis. Mar Biol 101:69-74

Swartz RC, Schultz DW, DeWitt TH, Ditsworth GR, Lamberson JO (1990) Toxicity of fluoranthene in sediment to marine amphipods: a test of the equalibrium partitioning approach to sediment quality critena. Environ Toxicol Chem 9:1071-1080

Tsutsumi H (1987) Population persistence of Capitella sp. (Polychaeta; Capitellidae) in an organically polluted cove. Mar Ecol Prog Ser 36:139-149

Tsutsumi H (1990) Population persistence of Capstella sp. (Polychaeta; Capitellidae) on a mud flat subject to environmental disturbance by organic enrichment. Mar Ecol Prog Ser 63:147-156

Tsutsumi H, Fugunaka S, Fujita N, Sumida M (1990) Relationship between growth of Capitella sp. and organic enrichment of the sediment. Mar Ecol Prog Ser 63:157-162

Tsutsumi $H$, Kikuchi $T$, Tanaka $M$, Higashi $T$, Imasaka $K$, Miyazaki M. (1991) Benthic fauna succession in a cove organically polluted by fish farming. Mar Pollut Bull 23: $233-238$

Wilkinson L (1990) SYSTAT: the system for statistics. SYSTAT, Inc, Evanston, IL 